\section{Molecular and Cellular Biology}

Guanine nucleotide activation of, and competition between, RAS proteins from Saccharomyces cerevisiae.

J Field, D Broek, T Kataoka and M Wigler Mol. Cell. Biol. 1987, 7(6):2128. DOI: 10.1128/MCB.7.6.2128.

Updated information and services can be found at: http://mcb.asm.org/content/7/6/2128

These include:

CONTENT ALERTS

Receive: RSS Feeds, eTOCs, free email alerts (when new articles cite this article), more» 


\title{
Guanine Nucleotide Activation of, and Competition between, RAS Proteins from Saccharomyces cerevisiae
}

\author{
JEFFREY FIELD, DANIEL BROEK, TOHRU KATAOKA, † AND MICHAEL WIGLER* \\ Cold Spring Harbor Laboratory, Cold Spring Harbor, New York 11724
}

Received 19 December 1986/Accepted 4 March 1987

\begin{abstract}
In the yeast Saccharomyces cerevisiae, yeast RAS proteins are potent activators of adenylate cyclase. In the present work we measured the activity of adenylate cyclase in membranes from Saccharomyces cerevisiae which overexpress this enzyme. The response of the enzyme to added RAS2 proteins bound with various guanine nucleotides and their analogs suggests that RAS2 proteins are active in their GTP-bound form and are virtually inactive in their GDP-bound form. Also, active RAS2 protein is not inhibited by inactive RAS2, suggesting that the inactive form does not compete with the active form in binding to its effector.
\end{abstract}

ras genes are ubiquitous in eucaryotes $(9,24,27,32)$. In mammals, they comprise a family of at least three members (H-, K-, and N-ras) which share structural and functional properties. They were first identified, in their mutant forms, as potent oncogenes $(4,5,7,12,22,26,29,33,36,38,39)$. Although the normal ras genes are not oncogenic, they too can cause the malignant transformation of cells when expressed at abnormally high levels (7). In mammals, Ras proteins are 21,000-dalton molecules that are localized to the cytoplasmic side of the cell membrane (44). They bind GTP and GDP (30) and have an intrinsic GTPase activity $(14,21$, 35). Moreover, some oncogenic forms of Ras protein are deficient in GTPase activity $(14,21,35)$. Based on these properties, and reasoning by analogy to other known guanine nucleotide-binding proteins, the $G$ proteins (reviewed in reference 15), most investigators think that Ras proteins act as transducers to convey extracellular signals to an intracellular effector pathway. According to this model, Ras protein bound to GTP activates its effector, and then shuts itself off through its intrinsic GTPase activity. Mutant Ras proteins which are defective in GTPase would thus cause abnormally prolonged stimulation of the effector system, explaining their oncogenicity.

The RAS1 and RAS2 proteins of the yeast Saccharomyces cerevisiae provide an ideal system for testing aspects of this model. They are structurally, biochemically, and functionally similar to the mammalian Ras proteins, and at least one of their effector systems is known $(3,9,10,18,24,37,41$, 42). The yeast $R A S$ genes were originally isolated by using mammalian ras genes as probes to screen libraries of $S$. cerevisiae genomic DNA. They encode proteins which are highly homologous to the mammalian Ras proteins, particularly at their amino termini $(9,24)$. They undergo processing events very similar to those of their mammalian counterparts and localize to membrane fractions $(8,13,25,31,44)$. Like the mammalian proteins, they bind guanine nucleotides; they have an intrinsic GTPase activity, and this activity is reduced in the mutant RAS2 $2^{\text {Val-19 }}$ protein which has an amino acid substitution analogous to one of the oncogenic forms of the mammalian Ras proteins (37, 41; unpublished observations). RAS1 and RAS2 proteins are activators of yeast

\footnotetext{
* Corresponding author.

† Present address: Department of Physiology and Biophysics, Harvard Medical School, Boston, MA 02115.
}

adenylate cyclase, and this appears to be their major physiological effector $(3,42)$.

We have previously shown that yeast and mammalian Ras proteins purified from Escherichia coli/vector expression systems are potent activators of the adenylate cyclase present in crude fractions of yeast membranes (3). Surprisingly, we observed that RAS2 protein bound to GDP appeared to activate adenylate cyclase although activation was only one half to one third that of RAS2 protein bound to a nonhydrolyzable GTP analog. We have since cloned the yeast gene encoding adenylate cyclase (17), and that has enabled us to create yeast strains which greatly overexpress that enzyme. As a result, we have been able to develop a more sensitive biochemical assay for Ras proteins. Using this system we have reexamined the guanine nucleotide dependence of RAS2 protein and conclude that RAS2 may be active only in its GTP-bound form. Moreover, we have found that RAS2 bound with a GDP analog does not compete with RAS2 bound with a GTP analog for activating its effector. This finding has relevance for understanding how overexpression of a normal Ras protein can be oncogenic.

\section{MATERIALS AND METHODS}

Construction of plasmid pADH-CYR1. The entire coding sequence of the CYRI gene was isolated from pCYRI-2(SalI) (17) by complete digestion with SalI and partial digestion with ClaI. The 8.1-kilobase fragment was cloned into YRp7, which was digested with SalI and ClaI to produce YRp7$C Y R I$ as shown in Fig. 1. YRp7 contains the TRPI marker and $A R S I$ for replication as a multicopy plasmid in $S$. cerevisiae (34). Then YRp7-CYRI was cleaved with SalI and ligated with a 400-base-pair SphI-HindIII fragment containing the yeast alcohol dehydrogenase promoter (1) after their cohesive ends were filled in or removed by treatment with Klenow fragment of $E$. coli DNA polymerase I. The $S p h \mathrm{I}$ HindIII fragment had been isolated from pLD94 obtained from L. Davidow and M. Gollahera of Pfizer Central Research (Groton, Conn.). The direction of the $A D H I$ promoter inserted was confirmed by the reconstruction of a Sall cleavage site at the junction of the filled-in SalI and SphI sites.

Growth of S. cerevisiae and construction of strain TK-B111. $S$. cerevisiae was grown in YPD (1\% yeast extract, $2 \%$ peptone, and $2 \%$ glucose) or, to maintain selective pressure for plasmids, in synthetic medium $(0.67 \mathrm{~g}$ of yeast nitrogen base per liter, $2 \%$ glucose, and appropriate auxotrophic 
supplements). General genetic manipulations of $S$. cerevisiae were performed as described by Mortimer and Hawthorne (23). Yeast transformations were performed as described (16). The strain TK-B111 (MAT $\alpha$ rasl::HIS3 ras2::URA3 trpl leu2 ade8 canl pADH-CYRI) was constructed by transforming the plasmid pADH-CYRI into strain SPK1 (MAT $\alpha$ ras1::HIS3 ras2::URA3 trpl leu2 ade8 canl pTLC-RAS2), followed by screening for segregants that lost the RAS2-bearing plasmid but retained pADH$C Y R 1$. The plasmid pTLC-RAS2 contains the yeast RAS2 gene cloned into a plasmid that confers sensitivity to canavanine. Details of this construction will be described elsewhere.

Preparation of yeast extracts and purification of RAS2. The preparation of yeast membrane extracts has been previously described $(3,42)$. RAS2 and RAS2 ${ }^{\text {Val-19 }}$ were purified from $E$. coli isolates containing expression systems as previously described (3). These $E$. coli strains express complete RAS2 proteins using the lambda $p_{\mathrm{L}}$ promoter.

Assays. Adenylate cyclase assays were performed as described $(3,28,42)$ except that an ATP-generating system was omitted. The legend to Fig. 3 describes a typical assay in more detail. All assays were carried out with $10 \mu \mathrm{g}$ of yeast extracts. Divalent cations, RAS2, and guanine nucleotides were varied as indicated in the figure legends. Incubations were for $30 \mathrm{~min}$ at $30^{\circ} \mathrm{C}$. The data are expressed as units of adenylate cyclase, where 1 unit catalyzed the formation of 1.0 pmol of cyclic AMP per min per mg of yeast membrane protein. Similar results were obtained with at least two preparations each of RAS2, RAS2 $2^{\mathrm{Val}-19}$, and yeast membrane extracts. The experiments reported here were carried out

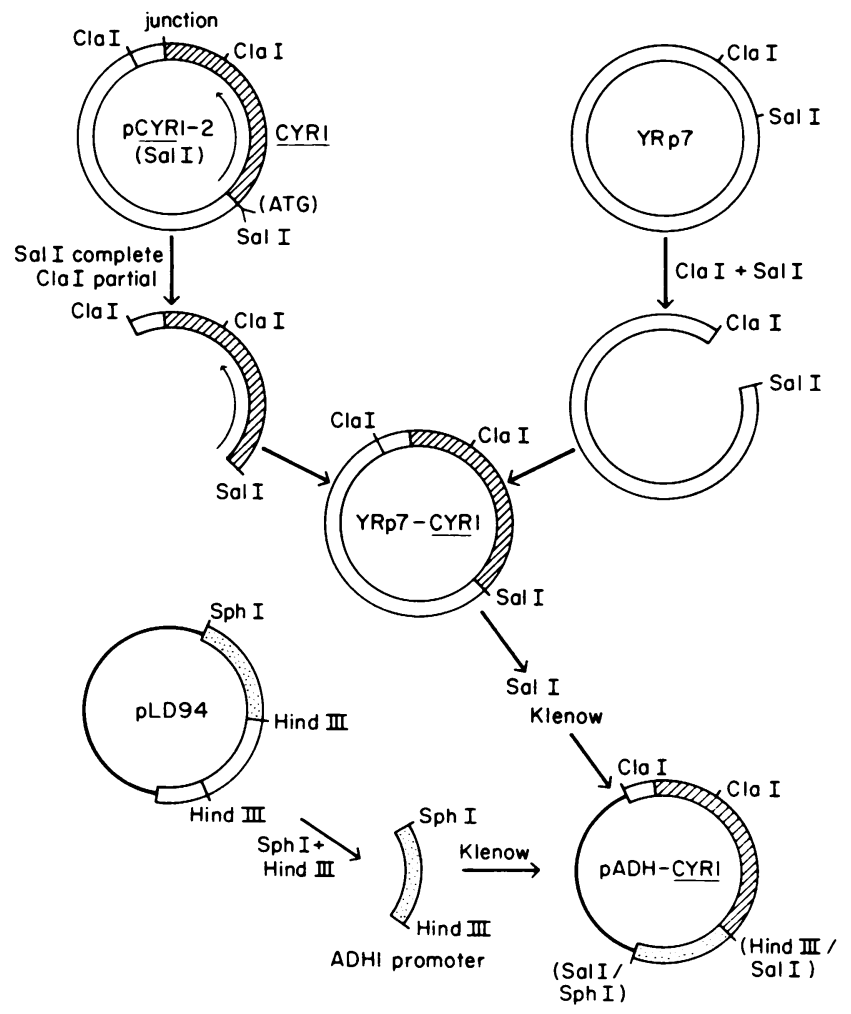

FIG. 1. Scheme for construction of the plasmid pADH-CYRI. This plasmid contains the entire open reading frame for the yeast adenylate cyclase gene expressed from the yeast alcohol dehydrogenase promoter. See Materials and Methods for details.

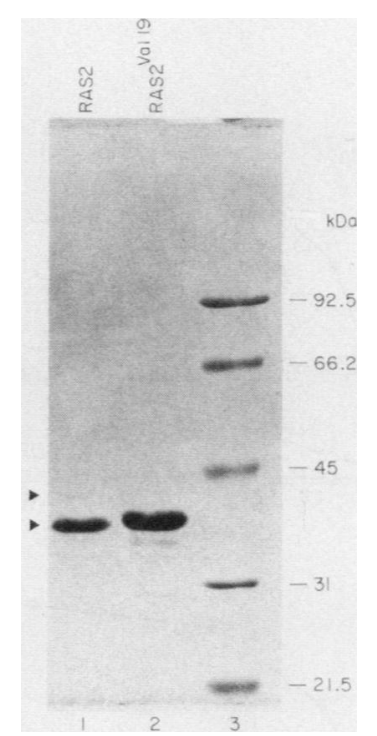

FIG. 2. Coomassieblue-stained sodiumdodecyl sulfate-polyacrylamide gel of purified $S$. cerevisiae RAS2 proteins. Lane 1. Wild-type RAS2, $5.6 \mu \mathrm{g}$; lane 2. RAS2 ${ }^{\mathrm{Val}-19}, 12.6 \mu \mathrm{g}$; lane 3 , markers. Molecular size of markers is indicated in $\mathrm{kDa}$. Arrows indicate bands that reacted with anti-RAS2 antiserum on Western blots.

with the same preparations of reagents and repeated at least twice. $\mathrm{Mn}^{2+}$ activity and maximum RAS activation varied by less than $50 \%$ between experiments, and duplicate data points within an experiment varied by less than $20 \%$. Guanine nucleotide binding was measured using a nitrocellulose filter binding assay. Protein assays were performed by the method of Bradford (2) with reagents from BioRad Laboratories (Richmond, Calif.).

\section{RESULTS}

Assay for RAS using membranes from cells which overexpress adenylate cyclase. Our present assays for RAS protein stimulation of adenylate cyclase differ from our previous assays in several significant respects. First, we use RAS2 protein extracted from an $E$. coli expression system intended to express the intact RAS2 protein. Previous studies utilized mainly an N-terminal fusion protein called f-RAS2 (3). Second, our source of yeast adenylate cyclase derives from membranes of yeast cells which greatly overexpress a cloned adenylate cyclase gene. As a consequence, the current assay has greater sensitivity. Thus, third, we have been able to omit an ATP-regenerating system. Fourth, we have performed guanine nucleotide exchange experiments with RAS2 in the presence of EDTA, since we have observed that nucleotide exchange is quite slow in the presence of free $\mathrm{Mg}^{2+}$ ions, and we monitored results with radiolabeled nucleotides.

The RAS2 proteins used in these studies were purified from an $E$. coli expression system which was previously described. Sodium dodecyl sulfate-polyacrylamide gels of the purified RAS2 and RAS2 $2^{\mathrm{Val}-19}$ proteins shown in Fig. 2 indicate that about $90 \%$ of the protein in this preparation is in a band of 37 kilodaltons ( $k D a)$, somewhat smaller than the 42-kDa protein predicted from the nucleotide sequence of RAS2. Indeed, Western blot analysis of the purified protein with an anti-RAS2 antiserum revealed two bands, one at 42 $\mathrm{kDa}$ and another at $37 \mathrm{kDa}$ (data not shown), suggesting that 

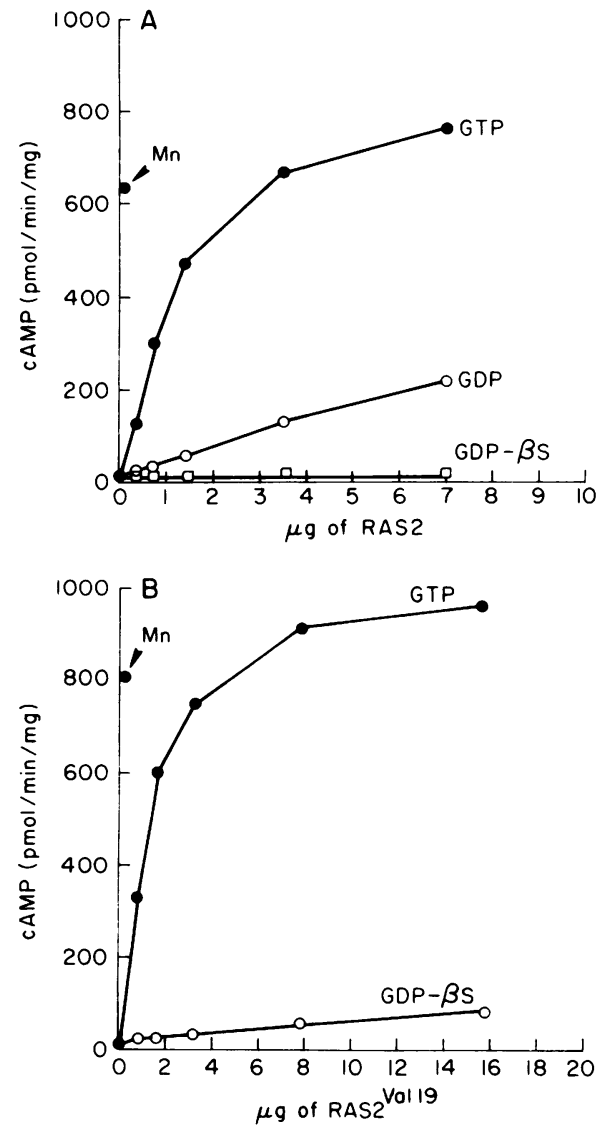

FIG. 3. Response of yeast adenylate cyclase to RAS2 proteins and guanine nucleotides (with accelerated exchange). (A) Effect of wild-type protein. Guanine nucleotide exchange reactions were monitored as follows. A 140- $\mu$ g sample of RAS2 was mixed with 10 $\mu \mathrm{Ci}$ of $\left[{ }^{3} \mathrm{H}\right] \mathrm{GDP}$, the "tracer" nucleotide, at $7 \mathrm{Ci} / \mathrm{mmol}$ in a total volume of $100 \mu$ l of buffer $\mathrm{G}(20 \mathrm{mM}$ Tris hydrochloride buffer, $\mathrm{pH}$ $7.5,20 \mathrm{mM} \mathrm{NaCl}, 5 \mathrm{mM} \beta$-mercaptoethanol, $3 \mathrm{mM} \mathrm{MgCl}$ ) supplemented with $7.5 \mathrm{mM}$ EDTA and then incubated for $30 \mathrm{~min}$ at $37^{\circ} \mathrm{C}$. A sample of $1.0 \mu \mathrm{l}$ was removed, and the $\left[{ }^{3} \mathrm{H}\right] \mathrm{GDP}$ bound to RAS2 was measured by binding to nitrocellulose filters. This value $(18,300$ $\mathrm{cpm}$ ) was used as the $100 \%$ point. Next, $15 \mu \mathrm{l}$ of the above reaction mixture was incubated with 15,000 pmol of the indicated "exchange" nucleotide in a volume of $30 \mu \mathrm{l}$ for $60 \mathrm{~min}$ at $37^{\circ} \mathrm{C}$ and then transferred to $0^{\circ} \mathrm{C}$. A portion $(2 \mu \mathrm{l})$ of this mixture was removed, and the $\left[{ }^{3} \mathrm{H}\right]$ GDP remaining bound to RAS2 was determined by filter binding. This determined the extent of nucleotide exchange or replacement (amounts of original nucleotide retained: with GTP added, 0.8\%; with GDP, 7.7\%; with GDP- $\beta$ S, 5.5\%). The remainder of the mixture was added to adenylate cyclase assays as follows. Samples ranging from 0.5 to $10.0 \mu \mathrm{l}$ were mixed with equal volumes of $15 \mathrm{mM} \mathrm{MgCl}_{2}$ to give an excess of $\mathrm{MgCl}_{2}$ over EDTA. Next, the samples were diluted to $20 \mu \mathrm{l}$ of buffer $\mathrm{G}$ containing the indicated guanine nucleotide, such that the final concentration of the nucleotide was $250 \mu \mathrm{M}$. Ten-microgram samples of membranes from rasl ${ }^{-}$ ras2- pADH-CYRI yeast strains (see Materials and Methods) were added in a volume of $30 \mu \mathrm{l}$, and the samples were incubated for 15 min at $0^{\circ} \mathrm{C}$. Next, $50 \mu l$ of assay mix was added to the following final concentrations: $20 \mathrm{mM}$ MES [2-( $N$-morpholino)ethanesulfonic acid; pH 6.2], $1 \mathrm{mM} \beta$-mercaptoethanol, $2.5 \mathrm{mM} \mathrm{MgCl}_{2}$ (or, where indicated, $2.5 \mathrm{mM} \mathrm{MnCl}$ ), $0.5 \mathrm{mM}$ cyclic AMP, $1 \mathrm{mM} \mathrm{ATP}$, and 20 $\mu \mathrm{Ci}$ of $\left[\alpha-{ }^{32} \mathrm{P}\right] \mathrm{ATP}(810 \mathrm{Ci} / \mathrm{mmol})$ to a specific activity of 100 to 300 $\mathrm{cpm} / \mathrm{pmol}$. Reactions were stopped, and cyclic AMP was measured. (B) Effects of RAS2 ${ }^{\mathrm{Val}-19}$ protein. This experiment was performed as described for panel A with the following modifications: RAS2 ${ }^{\text {Val-19 }}$ was used instead of RAS2, $10 \mu \mathrm{Ci}$ of $\left[\alpha-{ }^{32} \mathrm{P}\right] \mathrm{GTP}$ was used instead of $\left[{ }^{3} \mathrm{H}\right]$ GDP as the "tracer" nucleotide, the concentration of EDTA the $37-\mathrm{kDa}$ form of the RAS2 is a degradation product. Amino-terminal sequence analysis indicated that the RAS2 protein began with the second amino acid predicted from the DNA sequence (24). Thus the $37-\mathrm{kDa}$ product may lack up to 50 amino acids from the carboxyl terminus, including the cysteine residue(s) likely to be essential for posttranslational modifications and membrane targeting of Ras proteins in vivo (45). In Coomassie blue-stained gels, the percentage of the $42-\mathrm{kDa}$ band to the total RAS2 protein varied from less than the $10 \%$ shown in Fig. 2 to more than $50 \%$ in other preparations. However, all preparations were equally potent in binding guanine nucleotides and in activating adenylate cyclase. Apparently, modifications dependent upon an intact $\mathrm{C}$ terminus are not required for RAS2 function in vitro, as discussed by Powers et al. (25). Under saturating guanine nucleotide exchange conditions, 1 pmol of RAS2 or RAS2 $2^{\mathrm{Val}-19}$ bound 0.5 to 1.0 pmol of GDP (data not shown).

Our current assay system uses membranes from rasl $^{-}$ ras $2^{-}$cells which express greatly elevated levels of adenylate cyclase. To create such cells, we expressed the cloned yeast adenylate cyclase gene, $C Y R I$ (17), using the powerful yeast alcohol dehydrogenase promoter (1) and a high-copynumber plasmid, pADH-CYRI (Fig. 1). This plasmid is capable of suppressing the lethality which otherwise results from loss of both $R A S$ genes (data not shown) $(19,40)$. Membranes from the resulting rasl ${ }^{-}$ras2 ${ }^{-}$pADH-CYRIbearing strain contain approximately 20 -fold higher levels of adenylate cyclase activity than wild-type strains when assayed with $\mathrm{Mn}^{2+}$ as the divalent cation. The $\mathrm{Mn}^{2+}$. dependent adenylate cyclase activity is not dependent on RAS proteins $(3,6,42)$.

The adenylate cyclase expressed in abundance in the rasl $1^{-}$ras $2^{-}$pADH-CYRI strain is fully RAS responsive. In the absence of added RAS2 protein, we observed low $\mathrm{Mg}^{2+}$-dependent adenylate cyclase activity in membranes prepared from these strains. However (Fig. 3), activity could be stimulated 20 - to 50 -fold by purified RAS2 protein in the presence of both $\mathrm{Mg}^{2+}$ and GTP. As in previous experiments (3), stimulation was saturable, and, at the maximal level of stimulation, the $\mathrm{Mg}^{2+}-\mathrm{RAS2}-\mathrm{GTP}$-stimulated activity was about equal to the $\mathrm{Mn}^{2+}$-stimulated activity. The maximum level of stimulation by RAS2 protein was 20- to 50-fold higher than the maximum previously observed in rasl ${ }^{-}$ ras $2^{-}$membranes. These experiments suggest that if RAS proteins act on adenylate cyclase through an intermediate protein, this intermediate protein is not present in limiting amounts in the pADH-CYRI-bearing strain.

In most of the assays presented below, we monitored the extent of guanine nucleotide binding to RAS2 protein. To do this, we first bound a small amount of a radioactive "tracer" nucleotide to RAS2 protein. We then incubated the protein with the unlabeled nucleotide we wished to bind. The extent to which the tracer was displaced was determined by a nitrocellulose filter binding assay. As our work progressed it became clear that RAS2 protein purified from $E$. coli must come already bound with a guanine nucleotide, and that guanine nucleotide binding is actually an exchange reaction

was $25 \mathrm{mM}$ during guanine nucleotide exchange, and the concentration of $\mathrm{MgCl}_{2}$ used to chelate the additional EDTA was 40 $\mathrm{mM}$. Also, the concentration of GDP- $\beta S$ was increased to $1 \mathrm{mM}$. These changes were required to maximize exchange of the $\left[\alpha-{ }^{32} \mathrm{P}\right]$ GTP. The $100 \%$ point in this experiment corresponds to 51,200 cpm. Amounts of original nucleotide retained: with GTP added, 13\%; with GDP- $\beta$ S, $5.5 \%$. 
TABLE 1. Guanine nucleotide exchange in presence of $\mathrm{MgCl}_{2}{ }^{a}$

\begin{tabular}{|c|c|c|c|}
\hline \multirow{2}{*}{$\begin{array}{l}\text { Exchange } \\
\text { nucleotide }\end{array}$} & \multirow{2}{*}{$\begin{array}{l}\text { Labeled tracer } \\
\text { nucleotide }\end{array}$} & \multicolumn{2}{|c|}{ \% Label retained } \\
\hline & & RAS2 & RAS2 $^{\text {Val-19 }}$ \\
\hline None & {$\left[{ }^{3} \mathrm{H}\right] \mathrm{GDP}$} & 100 & 100 \\
\hline GDP & {$\left[{ }^{3} \mathrm{H}\right] \mathrm{GDP}$} & 57 & 78 \\
\hline GTP & {$\left[{ }^{3} \mathrm{H}\right]$ GDP } & 59 & 81 \\
\hline Gpp(NH)p & {$\left[{ }^{3} \mathrm{H}\right] \mathrm{GDP}$} & 56 & 78 \\
\hline GDP- $\beta S$ & {$\left[{ }^{3} \mathrm{H}\right] \mathrm{GDP}$} & 54 & 84 \\
\hline None & {$\left[{ }^{32} \mathrm{P}\right] \mathrm{GTP}$} & 100 & 100 \\
\hline GDP & $\left.{ }^{32} \mathrm{P}\right] \mathrm{GTP}$ & 73 & 83 \\
\hline GTP & {$\left[{ }^{32} \mathrm{P}\right] \mathrm{GTP}$} & 70 & 83 \\
\hline $\mathrm{Gpp}(\mathrm{NH}) \mathrm{p}$ & $\left.{ }^{32} \mathrm{P}\right] \mathrm{GTP}$ & 76 & 89 \\
\hline GDP- $\beta S$ & {$\left[{ }^{32} \mathrm{P}\right] \mathrm{GTP}$} & 72 & 88 \\
\hline
\end{tabular}

${ }^{a}$ RAS proteins were preincubated for 60 min with $1 \mu \mathrm{M}$ either $\left[\alpha-{ }^{32} \mathrm{P}\right] \mathrm{GTP}$ $(60,000 \mathrm{cpm} / \mathrm{pmol})$ or $\left[{ }^{3} \mathrm{H}\right] \mathrm{GDP}(3,000 \mathrm{cpm} / \mathrm{pmol})$ in the presence of buffer $\mathrm{G}$ (20 mM Tris hydrochloride buffer, pH 7.5, $20 \mathrm{mM} \mathrm{NaCl}, 5 \mathrm{mM} \beta$-mercaptoethanol, $3 \mathrm{mM} \mathrm{MgCl}$ ). RAS2 $(1.9 \mu \mathrm{g})$ or RAS2 $2^{\mathrm{Val}-19}(5.2 \mu \mathrm{g})$ was subsequently incubated with $50 \mu \mathrm{M}$ of the indicated exchange nucleotides. Incubations $(50 \mu \mathrm{l})$ were for $30 \mathrm{~min}$ at $37^{\circ} \mathrm{C}$ in the presence of buffer $\mathrm{G}$. The samples were then filtered through nitrocellulose filters. The value of $100 \%$ label retained represents the following absolute values: 24.3 pmol of GDP bound RAS2 $2^{\mathrm{Val}-19}, 23.9$ pmol of GDP-bound RAS2, 14.5 pmol of GTP-bound RAS2 $2^{\mathrm{Val}-19}$, and 14.8 pmol of GTP-bound RAS2.

which occurs slowly in the presence of free magnesium ions (Table 1). In the presence of EDTA, an $\mathbf{M g}^{2+}$ ion chelator, nucleotide exchange was greatly accelerated (see legend to Fig. 3). The slow exchange in the presence of free $\mathrm{Mg}^{2+}$ was exploited in one experiment (see Fig. 4).

Guanine nucleotide dependence of RAS2 proteins. We measured the ability of wild-type RAS2 and RAS2 ${ }^{\text {Val-19 }}$ proteins to stimulate the $\mathbf{M g}^{2+}$-dependent adenylate cyclase activity when bound to various guanine nucleotides. Adenylate cyclase was greatly stimulated by the addition of RAS2 or RAS2 ${ }^{\mathrm{Val}-19}$ proteins bound to GTP (Fig. 3). Saturation of the $\mathrm{Mg}^{2+}$-dependent adenylate cyclase activity was achieved at about $5 \mu \mathrm{g}$ of either RAS2-GTP or RAS2 ${ }^{\mathrm{Val}-19}$. GTP. As we have observed previously (3), RAS2 protein bound to GDP was able to activate adenylate cyclase, although only one fourth as well as protein bound to GTP (Fig. 3A). One possible explanation for this is that RAS2 bound to GDP is indeed a weak stimulator of adenylate cyclase. Another explanation is that, due to an ubiquitous dinucleotide kinase in cell membranes (20), the activity seen with RAS2 bound to GDP results from the conversion of free GDP to GTP followed by nucleotide exchange. Support for the latter explanation comes from experiments with the nucleotide GDP- $\beta S$ [guanosine-5'-O-(2-thiodiphosphate)], which cannot be directly converted to GTP. Very little stimulation of adenylate cyclase was observed after the addition of up to $7 \mu \mathrm{g}$ of RAS 2 or $16 \mu \mathrm{g}$ of RAS $2^{\mathrm{Val}-19}$ protein bound to GDP- $\beta S$ (Fig. 3). The inactive RAS2 proteins bound to GDP- $\beta$ S could activate adenylate cyclase after the readdition of GTP, indicating that the failure of RAS2-GDP$\beta S$ complexes to stimulate adenylate cyclase was not due to denaturation of the RAS2 proteins (data not shown). In experiments in which RAS2 was compared directly with RAS2 ${ }^{\text {Val-19 }}$, both activated adenylate cyclase with identical dose-response curves when in their GTP-bound state (data not shown). These experiments suggest that RAS2 and RAS2 ${ }^{\text {Val-19 }}$ proteins in their GTP-bound form are potent activators of yeast adenylate cyclase, whereas these proteins in their GDP-bound form may be virtually inactive. The difference in potency of the two forms may be as great as 20-fold. Recently, De Vendittis et al. reported similar results using wild-type yeast RAS2 (11).

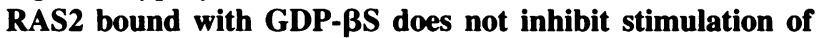
adenylate cyclase by RAS2 bound with Gpp(NH)p. The observations that nucleotide exchange occurs slowly in the presence of $\mathrm{Mg}^{2+}$ (Table 1) allowed us to test the competition between active and inactive forms of RAS2 (Fig. 4). To do this we bound wild-type RAS2 with Gpp(NH)p [guanosine-5' $(\beta, \gamma$-imino)triphosphate], a nonhydrolyzable GTP analog. Under conditions in which essentially complete nucleotide exchange could be demonstrated, Gpp(NH)pbound RAS2 activated adenylate cyclase as well as GTPbound RAS2 (not shown). We bound another sample of RAS2 to GDP- $\beta S$. Both nucleotides were bound to RAS2 in the presence of EDTA to accelerate exchange, and then the proteins were dialyzed to remove unbound nucleotide and EDTA. Adenylate cyclase assays were then performed without exogenously added nucleotide. As expected, Gpp(NH)p-bound RAS2 activated adenylate cyclase, and GDP- $\beta S$-bound RAS 2 did not activate adenylate cyclase. In competition assays the total amount of RAS2 was maintained at a saturating level, while the ratios of active to inactive RAS2 were varied over a 10-fold range. Essentially no inhibition was seen which could be attributed to competiton between the active and inactive forms of RAS2, although noncompetitive inhibition was observed in some, but not all experiments. Thus we conclude that the inactive form of RAS2 does not compete with the active form of RAS2 for the stimulation of adenylate cyclase. Essentially identical results were obtained using GDP- $\beta S$-bound RAS2 and GTP-bound RAS2 ${ }^{\text {Val-19 }}$ (data not shown).

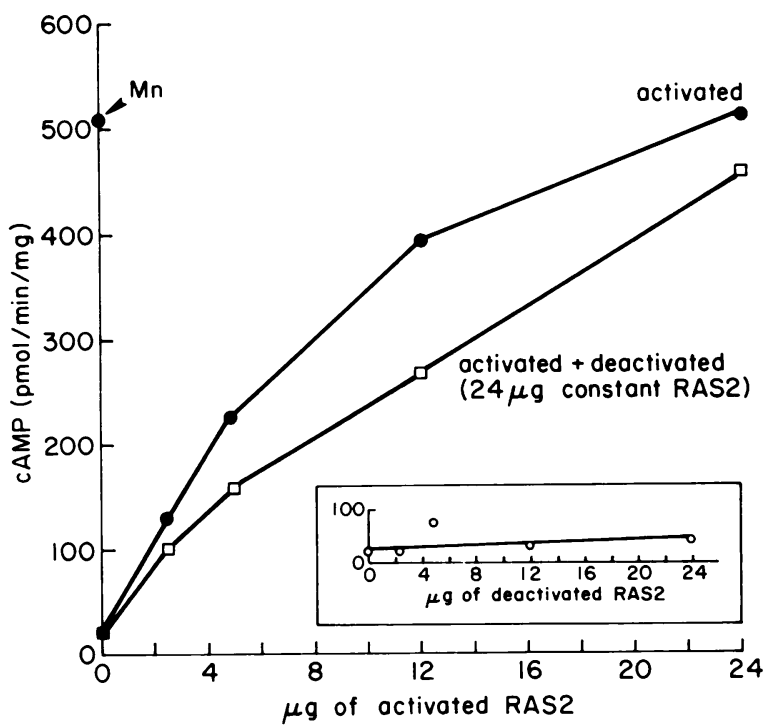

FIG. 4. Competition between Gpp(NH)p-bound RAS2 and GDP$\beta S$-bound RAS2. Wild-type RAS2 protein was treated with either GDP- $\beta S$ or Gpp(NH)p in the presence of $25 \mathrm{mM}$ EDTA in buffer $\mathrm{G}$ and then dialyzed against buffer $G$ containing $50 \%$ glycerol to remove unbound nucleotides. $\left[{ }^{3} \mathrm{H}\right] \mathrm{GDP}$ tracer binding indicated that 95\% exchange had occurred for GDP- $\beta$ S and $70 \%$ exchange had occurred for $\mathrm{Gpp}(\mathrm{NH}) \mathrm{p}$. When re-exchanged with GTP, each protein could activate adenylate cyclase as well as untreated protein (not shown). (O) Gpp(NH)p-treated RAS2 alone; (O) GDP- $\beta S$ treated RAS2; ( $\square$ ) Gpp(NH)p-treated RAS2 plus GDP- $\beta$ S-treated RAS2 (total RAS2 protein constant at $24 \mu \mathrm{g}$ ). The inset shows that RAS2 bound with GDB- $\beta S$ is inactive. 


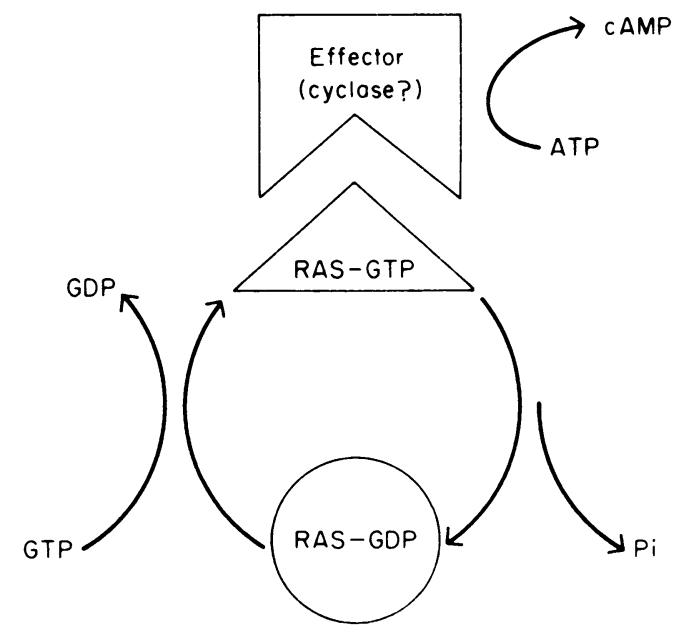

FIG. 5. Model for RAS2 activation of adenylate cyclase. See text for details.

\section{DISCUSSION}

We have modified the system for the in vitro biochemical assay of RAS protein function by using membranes from an $S$. cerevisiae strain overexpressing the adenylate cyclase gene. Interestingly, when overexpressed in $S$. cerevisiae. adenylate cyclase was fully responsive to RAS2. Thus, if there is an intermediate between RAS2 and adenylate cyclase, it is not present in limiting amounts. Another group has concluded that $S$. cerevisiae RAS proteins interact directly with adenylate cyclase, based on their report that the yeast adenylate cyclase gene, when expressed in $E$. coli is still activated by RAS (43). We have been unable to confirm these results (17). Moreover, the adenylate cyclase plasmid they used lacked regions of the gene which we know confer RAS regulation in $S$. cerevisiae (unpublished data). Further studies are required to determine whether RAS acts directly or indirectly on adenylate cyclase.

Our guanine nucleotide activation experiments (Fig. 3 and 4) suggest that both RAS2 and RAS2 ${ }^{\mathrm{Val}-19}$ activate yeast adenylate cyclase when in their GTP-bound state. As we previously reported, GDP-bound RAS is capable of weakly stimulating adenylate cyclase (3). However, based on results with the GDP analog GDP- $\beta S$ (Fig. 3 and 4), we believe that this weak stimulation results from rebinding of GTP regenerated from GDP. RAS2 bound to GDP- $\beta S$ is at most $10 \%$ as active as RAS2 bound to GTP. Although we cannot completely exclude that RAS2 bound to the GDP analog assumes a nonphysiological conformation, RAS2 in this form can be reactivated by the addition of GTP.

Our competition data suggest that the active GTP-bound form of RAS2 binds its effector, while the inactive, GDPbound form does not bind or does so less effectively. A simple consequence of the competition experiment is that the cellular signal due to RAS2 will be a function of the presence of the active form only, and not a function of the ratio of active to inactive forms. This is consistent with the genetic data in $S$. cerevisiae that the $R A S 2^{\mathrm{Val}-19}$ phenotype is dominant even in the presence of wild-type RAS2 (19). Taken together, our studies of RAS2 protein-adenylate cyclase interactions supports the model, shown in Fig. 5, in which RAS2 shuttles between a conformationally active GTP-bound state and an inactive GDP-bound state. The amount of time spent in the active state may be determined by the intrinsic GTP hydrolysis rate as well as by other proteins which may interact with RAS2. Only the active conformation binds its effector.

The mammalian $\mathrm{H}$-ras protein is capable of functioning in the $S$. cerevisiae system both in vivo and in vitro $(3,10,18)$, so it is tempting to extend our conclusions to the mammalian cell. Some oncogenic forms of mammalian ras genes encode proteins that, like the yeast $\mathrm{RAS} 2^{\mathrm{Val}-19}$ proteins, have reduced GTPase activity $(14,21,35)$. It has been proposed that transformation by these proteins results from a defective turn-off mechanism. Our experiments support this model, since they suggest that the GDP-bound form of RAS2 is virtually inactive. Moreover, mammalian cells can be transformed by overexpression of wild-type ras genes (7). Our competition data suggest that transformation in this case might result from an increase in the total amount of GTPbound Ras, even though the ratio of the GTP-bound Ras to the GDP-bound form might not change.

\section{ACKNOWLEDGMENTS}

We thank Scott Powers and Takashi Toda for providing yeast strains. Ottavio Fasano for discussing his data before publication, Daniel Marshak for his help with sequencing the purified RAS2 protein. and Patricia Bird for preparing this manuscript.

This work was supported by grants from the National Institutes of Health. the Pfizer Biomedical Research Award, the American Cancer Society. and the American Business Foundation for Cancer Research. J.F. is supported by the Anna Fuller Fund and the National Institutes of Health. D.B. is supported by the Damon Runyon-Walter Winchell Cancer Fund. M.W. is an American Cancer Society Professor.

\section{LITERATURE CITED}

1. Bennetzen, J. L., and B. D. Hall. 1982. The primary structure of the Saccharomyces cerevisiae gene for alcohol dehydrogenase I. J. Biol. Chem. 257:3018-3025.

2. Bradford, M. M. 1976. A rapid and sensitive method for the quantitation of microgram quantities of protein utilizing the principle of protein-dye binding. Anal. Biochem. 72:248-254.

3. Broek, D., N. Samiy, O. Fasano, A. Fujiyama, F. Tamanoi, J. Northup, and M. Wigler. 1985. Differential activation of yeast adenylate cyclase by wild-type and mutant $R A S$ proteins. Cell 41:763-769.

4. Capon, D. J., E. Y. Chen, A. D. Levinson, P. H. Seeburg, and D. V. Goeddel. 1983. Complete nucleotide sequences of the T24 human bladder carcinoma oncogene and its normal homologue. Nature (London) 302:33-37.

5. Capon, D. J., P. H. Seeburg, J. P. McGrath, J. S. Hayflick, U. Edman, A. D. Levinson, and D. V. Goeddel. 1983. Activation of $\mathrm{Ki}$-ras2 gene in human colon and lung carcinomas by two different point mutations. Nature (London) 304:507-513.

6. Casperson, G. F., N. Walker, A. R. Brasier, and H. R. Bourne. 1983. A guanine nucleotide-sensitive adenylate cyclase in the yeast Saccharomyces cerevisiae. J. Biol. Chem. 258:7911-7914.

7. Chang, E. H., M. E. Furth, E. M. Scolnick, and D. R. Lowy. 1982. Tumorigenic transformation of mammalian cells induced by a normal human gene homologous to the oncogene of Harvey murine sarcoma virus. Nature (London) 297:479-483.

8. Clark, S. G., J. P. McGrath, and A. P. Levinson. 1985. Expression of normal and activated human Ha-ras cDNAs in Saccharomyces cerevisiae. Mol. Cell. Biol. 5:2746-2752.

9. DeFeo-Jones, D., E. M. Scolnick, R. Koller, and R. Dhar. 1983. ras-related gene sequences identified and isolated from Saccharomyces cerevisiae. Nature (London) 306:707-709.

10. DeFeo-Jones, D., K. Tatchell, L. C. Robinson, I. Sigal, W. Vass, D. R. Lowy, and E. M. Scolnick. 1985. Mammalian and yeast ras gene products: biological function in their heterologous systems. Science 228:179-184.

11. De Vendittis, E., A. Vitelli, R. Zahn, and O. Fasano. 1986. Suppression of defective $R A S I$ and $R A S 2$ functions in yeast by 
an adenylate cyclase activated by a single amino acid change. EMBO J. 5:3657-3663.

12. Ellis, R. W., D. DeFeo, T. Y. Shih, M. Gonda, H. A. Young, N. Tsuchida, D. R. Lowy, and E. M. Scolnick. 1981. The p21 src genes of Harvey and Kirsten sarcoma viruses originate from divergent members of a family of normal vertebrate genes. Nature (London) 292:506-511.

13. Fujiyama, A., and F. Tamanoi. 1986. Processing and fatty acid acylation of RAS1 and RAS2 proteins in Saccharomyces cerevisiae. Proc. Natl. Acad. Sci. USA 83:1266-1270.

14. Gibbs, J. B., I. S. Sigal, M. Poe, and E. M. Scolnick. 1984. Intrinsic GTPase activity distinguishes normal and oncogenic ras p21 molecules. Proc. Natl. Acad. Sci. USA 81:5704-5708.

15. Gilman, A. 1984. G proteins and dual control of adenylate cyclase. Cell 36:577-579.

16. Ito, H., Y. Fukuda, K. Murata, and A. Kimura. 1983. Transformation of intact yeast cells treated with alkali cations. J. Bacteriol. 153:163-168.

17. Kataoka, T., D. Broek, and M. Wigler. 1985. DNA sequence and characterization of the $S$. cerevisiae gene encoding adenylate cyclase. Cell 43:493-505.

18. Kataoka, T., S. Powers, S. Cameron, O. Fasano, M. Goldfarb, J. Broach, and M. Wigler. 1985. Functional homology of mammalian and yeast $R A S$ genes. Cell 40:19-26.

19. Kataoka, T., S. Powers, C. McGill, O. Fasano, J. Strathern, J. Broach, and M. Wilger. 1984. Genetic analysis of yeast RASI and $R A S 2$ genes. Cell 37:437-445.

20. Kimura, N., and N. Shimada. 1983. GDP does not mediate but rather inhibits hormonal signal to adenylate cyclase. J. Biol. Chem. 258:2278-2283.

21. McGrath, J. P., D. J. Capon, D. V. Goeddel, and A. D. Levinson. 1984. Comparative biochemical properties of normal and activated human ras p21 protein. Nature (London) 310:644-649.

22. McGrath, J. P., D. J. Capon, D. H. Smith, E. Y. Chen, P. H. Seeburg, D. V. Goeddel, and A. D. Levinson. 1983. Structure and organization of the human $\mathrm{Ki}$-ras proto-oncogene and a related processed pseudogene. Nature (London) 304:501-506.

23. Mortimer, R. K., and D. C. Hawthorne. 1969. Yeast genetics, p. 385-460. In A. H. Rose and J. S. Harrison (ed.), The yeasts, vol. I. Academic Press, Inc., New York.

24. Powers, S., T. Kataoka, O. Fasano, M. Goldfarb, J. Strathern, J. Broach, and M. Wigler. 1984. Genes in S. cerevisiae encoding proteins with domains homologous to the mammalian ras proteins. Cell 36:607-612.

25. Powers, S., S. Michaelis, D. Broek, S. Santa Anna-A, J. Field, I. Herskowitz, and M. Wigler. 1986. RAM, a gene of yeast required for a functional modification of $R A S$ proteins and for production of mating pheromone a-factor. Cell 47:413-422.

26. Reddy, E. P., R. K. Reynolds, E. Santos, and M. Barbacid. 1982. A point mutation is responsible for the acquisition of transforming properties by the T24 human bladder carcinoma oncogene. Nature (London) 300:149-152.

27. Reymond, C. D., R. H. Gomer, M. C. Mehdy, and R. A. Firtel. 1984. Developmental regulation of a Dictyostelium gene encoding a protein homologous to mammalian ras protein. Cell 39:141-148.

28. Salomon, Y., C. Londos, and M. Rodbell. 1974. A highly sensitive adenylate cyclase assay. Anal. Biochem. 58:541-548.

29. Santos, E., S. R. Tronick, S. A. Aaronson, S. Pulciani, and M. Barbacid. 1982. T24 human bladder carcinoma oncogene is an activated form of the normal human homologue of BALB- and Harvey-MSV transforming gene. Nature (London) 298:343-347.
30. Scolnick, E. M., A. G. Papageorge, and T. Y. Shih. 1979. Guanine nucleotide-binding activity as an assay for $s r c$ protein of rat-derived murine sarcoma viruses. Proc. Natl. Acad. Sci. USA 76:5355-5359.

31. Shih, T. Y., M. O. Weeks, P. Gruss, R. Dhar, S. Oroszlan, and E. M. Scolnick. 1982. Identification of a precursor in the biosynthesis of the p21 transforming protein of Harvey murine sarcoma virus. J. Virol. 42:253-261.

32. Shilo, B.-Z., and R. A. Weinberg. 1981. DNA sequences homologous to vertebrate oncogenes are conserved in Drosophila melanogaster. Proc. Natl. Acad. Sci. USA 78:6789-6792.

33. Shimizu, K., D. Birnbaum, M. A. Ruley, O. Fasano, Y. Suard, L. Edlund, E. Taparowsky, M. Goldfarb, and M. Wigler. 1983. Structure of the Ki-ras gene of the human lung carcinoma cell line Calu-1. Nature (London) 304:497-500.

34. Struhl, K., D. T. Stinchcomb, S. Scherer, and R. W. Davis. 1979. High-frequency transformation of yeast: autonomous replication of hybrid DNA molecules. Proc. Natl. Acad. Sci. USA 76:1035-1039.

35. Sweet, R., S. Yokoyama, T. Kamata, J. Feramisco, $M$ Rosenberg, and M. Gross. 1984. The product of ras is a GTPase and the T24 onogenic mutant is deficient in this activity. Nature (London) 311:273-275.

36. Tabin, C. J., S. M. Bradley, C. I. Bargmann, R. A. Weinberg, A. G. Papageorge, E. M. Scolnick, R. Dhar, D. R. Lowy, and E. H. Chang. 1982. Mechanism of activation of a human oncogene. Nature (London) 300:143-149.

37. Tamanoi, F., M. Walsh, T. Kataoka, and M. Wigler. 1984. A product of yeast $R A S 2$ gene is a guanine nucleotide binding protein. Proc. Natl. Acad. Sci. USA 81:6924-6928.

38. Taparowsky, E., K. Shimizu, M. Goldfarb, and M. Wigler. 1984 Structure and activation of the human N-ras gene. Cell 34:581-586.

39. Taparowsky, E., Y. Suard, O. Fasano, K. Shimizu, M. Goldfarb, and M. Wigler. 1982. Activation of the T24 bladder carcinoma transforming gene is linked to a single amino acid change. Nature (London) 300:762-765.

40. Tatchell, K., D. T. Chalefi, D. DeFeo-Jones, and E. M. Scolnick. 1984. Requirement of either of a pair of ras-related genes of Saccharomyces cerevisiae for spore viability. Nature (London) 309:523-527.

41. Temeles, G. L., J. B. Gibbs, J. S. D'Alonzo, I. S. Sigal, and E. M. Scolnick. 1984. Yeast and mammalian ras proteins have conserved biochemical properties. Nature (London) 313:700703.

42. Toda, T., I. Uno, T. Ishikawa, S. Powers, T. Kataoka, D. Broek, S. Cameron, J. Broach, K. Matsumoto, and M. Wigler. 1985. In yeast, RAS proteins are controlling elements of adenylate cyclase. Cell 40:27-36.

43. Uno, I., H. Mitsuzawa, K. Matsumoto, K. Tanaka, T. Oshima, and T. Ishikawa. 1985. Reconstitution of the GTP-dependent adenylate cyclase from products of the yeast $C Y R I$ and $R A S 2$ genes in Escherichia coli. Proc. Natl. Acad. Sci. USA 82:7855-7859.

44. Willingham, M. C., I. Pastan, T. Y. Shih, and E. M. Scolnick. 1980. Localization of the src gene product of the Harvey strain of MSV to plasma membrane of transformed cells by electron microscopic immunocytochemistry. Cell 19:1005-1014.

45. Willumsen, B. M., K. Norris, A. G. Papageorge, N. L. Hubbert, and D. R. Lowy. 1984. Harvey murine sarcoma virus p21 ras protein: biological and biochemical significance of the cysteine nearest the carboxy terminus. EMBO J. 3:2581-2585. 